\title{
ЗМІНИ ПОКАЗНИКІВ ЛІПОПЕРОКСИДАЦІЇ ПРИ ЕКСПЕРИМЕНТАЛЬНОМУ ПАРОДОНТИТІ БАКТЕРІАЛЬНО-ІМУННОГО ГЕНЕЗУ ТА ВПЛИВ НА НИХ КВЕРЦЕТИНУ
}

Зміни показників ліпопероксидації при експериментальному пародонтиті бактеріальноімунного генезу та вплив на них кверцетину

\section{А. Є. Демкович}

Тернопільський національний медичний університет імені І. Я. Горбачевського МОЗ України

Резюме. Активація пероксидного окиснення ліпідів і зниження антиоксидантної активності порушують динамічну стабільність мембран еритроцитів і сприяють розвитку патологічного процесу в пародонтальному комплексі. Багатофракторний патогенез генералізованого пародонтиту передбачає адекватний вибір та призначення лікарських препаратів. Особливу увагу заслуговують деякі фрлавоноїди рослиного походження, зокрема кверцетин. Антиоксидантна активність препарату пов'язана з його здатністю пригнічувати пероксидне окиснення ліпідів, знижувати концентрацію вільних радикалів і токсичних продуктів пероксидації, стимулювати каталазну і супероксиддисмутазну активність організму.

Мета дослідження - 3'ясувати вплив фрлавонолу кверцетину на показники ліпопероксидації у сироватці крові при експериментальному пародонтиті бактеріально-імунного генезу.

Матеріали і методи. Проведені біохімічні дослідження показників активності вільнорадикальних процесів у сироватці крові, які оцінювали за вмістом дієнових (ДК) $i$ трієнових кон'югатів (ТК) на 14-ту добу дослідження при розвитку експериментального пародонтиту як до, так і після використання водорозчинної фрорми фрлавонолу кверцетину - препарату «Корвітин», який вводили дослідним тваринам внутрішньом'язово у дозі 100 мг/ка маси тварини упродовж 7-ми діб (з 7-ї до 14-ї доби).

Результати. У даній статті висвітлюється вивчення особливостей процесів ліпопероксидації в білих щурів у різні періоди розвитку експериментального пародонтиту. В процесі фрормування експериментального бактеріально-імунного запального процесу в пародонтальному комплексі, який включав відрізок часу з 1-ї до 14-і доби експериментального спостереження, відбувалося надмірне накопичення в сироватці крові продуктів ліпопероксидації, про що свідчило зростання концентрації вмісту в сироватці крові дієнових і трієнових кон'югатів. Застосування антиоксиданту фрлавоноїдного походження кверцетину приводило до зниження вмісту продуктів ліпопероксидації у сироватці крові тварин.
Changes of lipoperoxidation indicators in experimental periodontitis of bacterial-immune genesis and effect of quercetin on them

\section{A. Ye. Demkovych}

I. Horbachevsky Ternopil National Medical University

e-mail: demkovushae@tdmu.edu.ua

Summary. Activation of lipid peroxidation and reduction of antioxidant activity disrupt the dynamic stability of erythrocyte membranes and contribute to the development of a pathological process in the periodontal complex. Multifactorial pathogenesis of generalized periodontitis involves adequate selection and prescription of drugs. Some flavonoids of plant origin, in particular quercetin, deserve special attention. Antioxidant activity of the drug is associated with its ability to inhibit lipid peroxidation, reduce the concentration of free radicals and toxic peroxidation products, stimulate catalase and superoxide dismutase activity of the organism.

The aim of the study - to determine the effect of flavonol quercetin on serum lipoperoxidation in experimental periodontitis of bacterial-immune genesis.

Materials and Methods. Biochemical studies of the activity of free radical processes in blood serum were performed, which were evaluated by the content of diene conjugates and triene conjugates on the $14^{\text {th }}$ day of the study in the development of experimental periodontitis both before and after the use of water-soluble form of flavonol quercetin was administered to experimental animals intramuscularly at a dose of $100 \mathrm{mg} / \mathrm{kg}$ of animal weight for 7 days (from the $7^{\text {th }}$ to the $14^{\text {th }}$ day).

Results. This article covers the study of the peculiarities of lipoperoxidation processes in white rats in different periods of development of experimental periodontitis. In the process of forming an experimental bacterial-immune inflammatory process in the periodontal complex, which included the period from the $1^{\text {st }}$ to the $14^{\text {th }}$ day of experimental observation, there was an excessive accumulation in the serum of lipoperoxidation products, as evidenced by an increase in serum diene and triene conjugates. The use of the antioxidant flavonoid origin of quercetin led to a decrease in the content of lipoperoxidation products in the serum of animals.

Conclusions. In experimental periodontitis, products of lipid peroxidation accumulate, which affects the nature of the course and completion of the 
Висновки. При експериментальному пародонтиті нагромаджуються продукти пероксидації ліпідів, що впливає на характер перебігу і завершення запального процесу. Значне збільшення вмісту ДК і ТК вказує на роль активності процесів вільнорадикального окиснення ліпідів у розвитку запалення в механізмах фрормування його бактеріального та імунного компонентів. Флавонол кверцетин стабілізує прооксидантну систему в процесі перебігу експериментального бактеріально-імунного пародонтиту.

Ключові слова: пародонтит; запалення; ліпопероксидація; дієнові кон'югати; трієнові кон'югати; фрлавонол; кверцетин.

\section{ВСТУП}

На даний час недостатньо вивчено патогенез розвитку запального процесу в пародонті, зокрема порушень процесів пероксидного окиснення ліпідів, білків, нітроксидергічних процесів, недостатності фрункціонального стану системи антиоксидантного захисту, клітинної й гуморальної ланок імунного захисту, цитокіногенезу та ендотоксикозу [1]. Розвиток запально-деструктивних змін у тканинах пародонтального комплексу пов'язують із порушеннями мікроциркуляції і транскапілярного обміну на тлі вираженої гіпоксії. 3 усіх наслідків і ускладнень гіпоксії найбільш серйозним $є$ інтенсифрікація вільнорадикального окислення і пригнічення антиоксидантного захисту біологічних тканин і середовищ [2]. Активація пероксидного окиснення ліпідів (ПОЛ) є пусковим механізмом стресорних ушкоджень із порушенням метаболізму клітин, які перш за все пов'язані 3 ушкодженням клітинних і субклітинних мембран [3].

Активація ПОЛ і зниження антиоксидантної активності сприяють накопиченню вільного холестеролу, етерифікованого холестеролу, лізофосоратидів, кардіоліпіну, фоссратидилхоліну, зниженню неетерифікованих жирних кислот та ін. [4]. Ці зміни порушують динамічну стабільність мембран еритроцитів і сприяють розвитку патологічного процесу в пародонтальному комплексі [2].

Відомі фракти про роль оксидативного стресу в патогенезі пародонтитів дозволяють розглядати активність переокиснення ліпідів у сироватці крові та слині та її антиокиснювальний потенціал як потенційні предиктори ескалації запального ураження пародонта [5].

Установлено порушення антиоксидантного захисту у хворих на генералізований парадонтит (ГП), що виявлено за змінами активності каталази, церулоплазміну та насиченості трансорерину залізом і збільшенням рівня дієнових (ДК) і трієнових кон'югатів (ТК) у сироватці крові, яке призводить до розвитку синдрому ендогенної інтоксикації у хворих на генералізований пародонтит [6].

Поліетіологічність та складний багатофакторний патогенез генералізованого пародонтиту пе- inflammatory process. A significant increase in the content of DC and TC indicates the role of the activity of free radical oxidation of lipids in the development of inflammation in the mechanisms of formation of its bacterial and immune components. Flavonol quercetin stabilizes the prooxidant system during experimental bacterial-immune periodontitis.

Key words: periodontitis; inflammation; lipoperoxidation; diene conjugates; triene conjugates; flavonol; quercetin.

редбачає адекватний вибір та призначення лікарських препаратів, комплексний підхід залежно від глибини ушкодження тканин пародонта, перебігу захворювання та клінічних проявів ГП [7, 8]. Необхідно зазначити, що особливу увагу заслуговують деякі фрлавоноїди рослиного походження, зокрема кверцетин. Антиоксидантна активність препарату пов'язана з його здатністю пригнічувати пероксидне окиснення ліпідів, знижувати концентрацію вільних радикалів і токсичних продуктів пероксидації, стимулювати каталазну і супероксиддисмутазну активність організму, захищає мембрани клітин від ушкодження, зменшує проникність капілярів $[9,10]$. Варто зазначити, що кверцетин також сприяє активації фрерментів власної антиоксидантної системи, протеїнкінази, ензимів продукції оксиду азоту тощо [11]. Особлива біологічна дія фрлавонолу проявляється у його здатності хелатувати іони зі змінною валентністю та вступати в реакцію 3 вільними радикалами, запобігаючи утворенню гіпохлорит-аніона [12]. Завдяки френольній структурі кверцетину його молекули взаємодіють із вільними радикалами, зменшуючи інтенсивність пероксидного окиснення ліпідів, що сприяє зниженню утворення основного негативного фрактора - малонового діальдегіду [13]. Даному фрлавонолу властива енергозберігаюча дія, а також здатність коригувати порушення вуглеводного обміну за умов прогресуючого ендотоксикозу $[14,15]$.

Метою дослідження було з'ясувати вплив фрлавонолу кверцетину на показники ліпопероксидації у сироватці крові при експериментальному пародонтиті бактеріально-імунного генезу.

\section{МАТЕРІАЛИ I МЕТОДИ}

Експерименти було проведено на білих статевозрілих щурах-самцях. Відібраних для дослідження тварин утримували у віварії ДВН3 «Тернопільський державний медичний університет імені І. Я. Горбачевського МОЗ України» на стандартному раціоні відповідно до санітарно-гігієнічних норм і вимог GLP. Оперативні втручання 
проводили із дотриманням загальних правил i положень Європейської конвенції із захисту хребетних тварин, які використовуються для дослідних та інших наукових цілей (Страсбург, 1986), Загальних етичних принципів експериментів на тваринах (Київ, 2001), Закону України «Про захист тварин від жорстокої поведінки» (2006). Після тіопенталового знеболювання (у дозі 40 мг/кг внутрішньом'язово) щура фріксували у станку. Проведена підокістна ін'єкція 0,01 мл яєчного білка із культурами гемолітичного стрептокока і золотистого стафрілокока у дозі 4 КУО в ділянку тканин пародонта нижнього різця як ініціюючого запалення фрактора. Для підсилення імунних процесів одночасно було введено у лапку задньої кінцівки тварини повний ад'ювант Фрейнда [16]. Дані групи тварин досліджували на 14-ту добу. Для корекції використовували водорозчинну фрорму фрлавонолу кверцетину - препарату «Корвітин», який вводили дослідним тваринам внутрішньом'язово у дозі 100 мг/кг маси тварини упродовж 7-ми діб (з 7-ї до 14-ї доби). Концентрацію дієнових і трієнових кон'югатів визначали за методом, який ґрунтувався на тому, що екстраговані гептан-ізопропіловою сумішшю гідроперекиси мали відповідний максимум поглинання: ДК при довжині хвилі 232 нм; ТК при довжині хвилі 275 нм [17]. До 0,2 мл сироватки додавали 4 мл суміші гептан-ізопропанолу (1:1) і струшували 15 хв на лабораторному струшувачі. Потім у пробірки додавали по 1 мл розчину гідрохлоридної кислоти $(\mathrm{pH}=2,0)$ і 2 мл гептану, інтенсивно струшували і після відстоювання та розшарування суміші (через 30 хв) відбирали гептановий шар та вимірювали його оптичну щільність на спектрофотометрі СФ-46 при $\lambda=232$ нм (275 нм). Як контроль використовували пробу, що містила 0,2 мл дистильованої води замість досліджуваного матеріалу. Вміст виражали в ум. од./мл у сироватці крові. Статистичну обробку цифрових даних здійснювали за допомогою програмного забезпечення STATISTICA 10.0 (Statsoft, США) 3 використанням варіаційно-статистичних методів оцінки одержаних даних [18].

\section{РЕЗУЛЬТАТИ Й ОБГОВОРЕННЯ}

У результаті досліджень встановлено, що в процесі формування експериментального бактеріально-імунного запального процесу в пародонтальному комплексі, який включав відрізок часу 3 1-ї до 14-ї доби експериментального спостереження, відбувалося надмірне накопичення в сироватці крові продуктів ліпопероксидації, про що свідчило зростання концентрації вмісту в сироватці крові дієнових і трієнових кон'югатів у 1,44 раза $(p<0,01)$ i в 1,26 раза $(p<0,01)$ відповідно, порівняно 3 контрольною групою тварин (табл.).

Одержані показники є результатом активації процесів вільнорадикального окиснення ліпідів упродовж усіх етапів фрормування запальної реакції та свідченням генерації активних фрорм кисню на достатньо високому рівні.

При визначенні співвідношення вмісту ДК/ТК у сироватці крові виявилося, що даний показник вірогідно збільшився на 14-ту добу дослідження (в 1,16 раза; $p<0,01)$ порівняно 3 показниками контрольної групи.

Застосування антиоксиданту фрлавоноїдного походження кверцетину впродовж 7-ми діб внутрішньом'язово у дозі 100 мг/кг приводило до зниження вмісту дієнових в 1,23 раза $(p<0,01)$ та трієнових кон'югатів - в 1,18 раза $(p<0,01)$ у сироватці крові проти групи тварин із запаленням у пародонтальному комплексі в такий же термін, які не отримували даного препарату з антиоксидантними властивостями, що свідчить про його стабілізуючий вплив на процеси оксидації ліпідів та перебіг запального процесу (рис.).

Необхідно при цьому відмітити, що рівні даних продуктів пероксидації після проведеної корекції все ж таки залишалися вищими від показників контрольної групи експериментальних тварин - ДК

Таблиця. Вміст дієнових і трієнових кон'югатів у сироватці крові дослідних тварин за умови експериментального

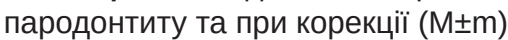

\begin{tabular}{l|c|c|c}
\hline \multirow{2}{*}{ Умова та показник досліду } & $\begin{array}{c}\text { Контрольна група, } \\
\text { інтактні тварини }\end{array}$ & \multicolumn{2}{|c}{ Тварини з експериментальним пародонтитом } \\
\cline { 3 - 4 } & - & без корекції & 3 корекцією кверцетином \\
\hline Тривалість експерименту, діб & 10 & 14 & 14 \\
\hline Кількість щурів & $2,383 \pm 0,071$ & $\begin{array}{c}3,431 \pm 0,089 \\
p_{1}<0,01\end{array}$ & $\begin{array}{c}2,781 \pm 0,030 \\
p_{1}<0,01 ; p_{2}<0,01\end{array}$ \\
\hline ДК, ум. од./мл & $2,756 \pm 0,022$ & $\begin{array}{c}3,485 \pm 0,107 \\
p_{1}<0,01\end{array}$ & $\begin{array}{c}2,949 \pm 0,021 \\
p_{1}<0,01 ; p_{2}<0,01\end{array}$ \\
\hline ТК, ум. од./мл & $0,86 \pm 0,03$ & $\begin{array}{c}1,00 \pm 0,04 \\
p_{1}<0,01\end{array}$ & $\begin{array}{c}0,94 \pm 0,01 \\
p_{1}<0,05 ; p_{2}>0,01\end{array}$ \\
\hline ДК/ТК & &
\end{tabular}

Примітки: 1) р $_{1}$ - достовірність відмінностей відносно інтактних тварин;

2) $p_{2}$ - достовірність відмінностей відносно тварин із експериментальним пародонтитом на 14-ту добу дослідження без корекції кверцетином 


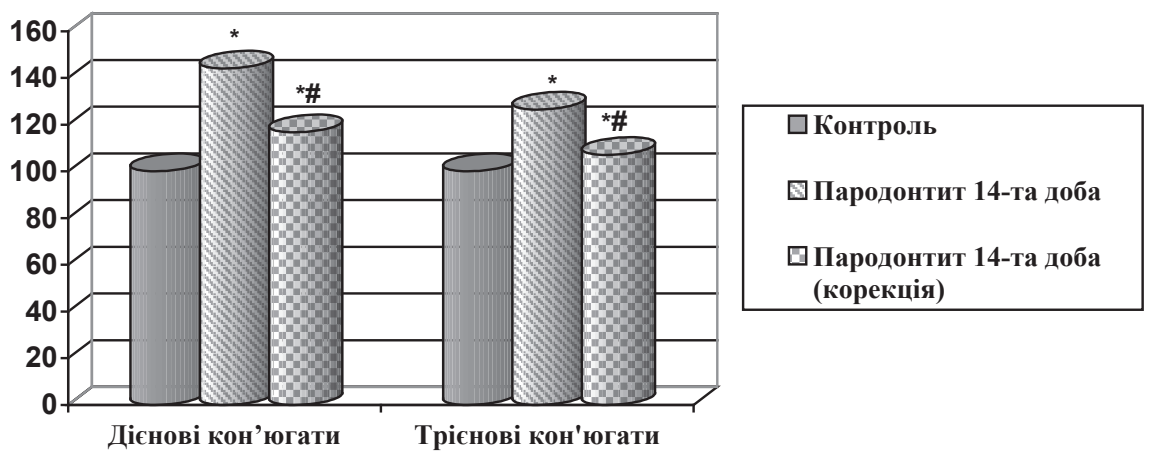

Рис. Порівняння динаміки вмісту дієнових і трієнових кон'югатів у сироватці крові експериментальних тварин за умов розвитку експериментального пародонтиту бактеріально-імунного генезу та при корекції кверцетином (у \% від контрольної групи).

Примітки: 1) * - достовірність відмінностей відносно інтактних тварин $(p<0,01)$;

2) \# - достовірність відмінностей відносно тварин із пародонтитом на 14-ту добу експерименту без корекції кверцетином (р<0,01).

$$
\begin{aligned}
& \text { в } 1,17 \text { раза }(\mathrm{p}<0,01), \text { ТК - у 1,07 раза }(\mathrm{p}<0,01) \text { від- } \\
& \text { повідно. }
\end{aligned}
$$

При порівнянні між собою співвідношення ДК/ ТК у щурів на 14-ту добу як до, так і після введення кверцетину, відмінності були статистично невірогідними $(p<0,05)$.

Отже, дані, які ми дослідили, дають підставу стверджувати, що використання фрлавонолу кверцетину в формі водорозчинного препарату «Корвітин» свідчать про його стабілізуючий вплив на процеси вільнорадикального окиснення та виявляють позитивний коригуючий вплив на вміст у сироватці крові дієнових і трієнових кон'югатів за умов експериментального пародонтиту бактеріально-імунного генезу.

\section{СПИСОК ЛІТЕРАТУРИ}

1. Demkovych A. Ye. Changes of antioxidant potential under the experimental periodontitis development / A. Ye. Demkovych, Yu. І. Bondarenko // Фізіологічний журнал. - 2018. - Т. 64, № 3. - С. 43-51.

2. Окислительный стресс и комплексная антиоксидантная энергокоррекция в лечении пародонтита / И. А. Омаров [и др.] // Стоматология. - 2011. - Т. 90, № 1. - C. 10-17.

3. Нестеров Ю. В. Структурные особенности аэрогематического барьера легких в условиях острого гипо- и гипероксического стресса / Ю. В. Несторов, Н. В. Турченков // Естественные науки. - 2010. - № 3. C. 112-116.

4. Oxidative stress in asthma / U. M. Sahiner, E. Birben, S. Erzurum [et al.] // World Allergy Organ. - 2011. - Vol. 4, No. 10. - P. 151-158.

5. Reactive oxygen species in periodontitis / P. Dahiya, R. Kamal, R. Gupta [et al.] // J. Indian. Soc. Periodontol. 2013. - Vol. 17, No. 4. - P. 411-416.

6. Бутюгин И. А. Состояние системы перекисное окисление липидов - антиоксидантная защита в смешанной слюне у больных хроническим генерализованным пародонтитом / И. А. Бутюгин, И. А. Волчегорский // Кли-

\section{ВИСНОВКИ}

1. У динаміці розвитку запального процесу пародонтального комплексу з бактеріально-імунним компонентом нагромаджуються продукти пероксидації ліпідів, що впливає на характер перебігу і завершення запального процесу. Значне збільшення вмісту ДК і ТК вказує на роль активності процесів вільнорадикального окиснення ліпідів у розвитку запалення в механізмах фрормування його бактеріального та імунного компонентів.

2. Флавонол кверцетин стабілізує прооксидантну систему в процесі перебігу експериментального бактеріально-імунного пародонтиту, що проявляється зниженням вмісту дієнових, трієнових кон'югатів у сироватці крові дослідних тварин і сприяє стаціонарному перебігу запального процесу.

ническая лабораторная диагностика. - 2014. - № 2. C. 44-47.

7. Дурягіна Л. Х. Вплив депресивних розладів на стан тканин пародонта і слизової оболонки порожнини рота / Л. Х. Дурягіна, В. П. Седих, О. В. Дорофеєєва // Таврический медико-биологический вестник. - 2014. T. 17, № 1. - C. 47-50.

8. Genco R. J. Risk factors for periodontal disease. Risk assessment and periodontal prevention in primary care / R. J. Genco, W. S. Garcia, R. Compton // Periodontol. 2000. - 2016. - Vol. 71, No. 1. - P. 10-21.

9. Demkovych A. Effects of flavonol quercetin on activity of lipid peroxide oxidation in experimental bacterialimmune periodontitis / A. Demkovych // Interventional Medicine and Applied Science. - 2019. - Vol. 11, No. 1. - P. 55-59.

10. Demkovych A. Effects of quercetin on antioxidant potential in the experimental periodontitis development / A. Demkovych, Yu. Bondarenko, P. Hasiuk // Interventional Medicine and Applied Science. - 2019. - Vol. 11, No. 1. P. 60-64.

11. Flavonoids, antioxidant activity and aroma compounds analysis from different kinds of tartary buckwheat 
tea / L. X. Peng, L. Zou, J. B. Wang [et al.] // Indian. J. Pharm. Sci. - 2015. - Vol. 77, No. 6. - P. 661-667.

12. Ebrahimpour, S. (2018). Effect of quercetin-conjugated superparamagnetic iron oxide nanoparticles on diabetes-induced learning and memory impairment in rats / S. Ebrahimpour, A. Esmaeili, S. Beheshti // Int. J. Nanomedicine. - 2018. - No. 13. - P. 6311-6324.

13. Effects of functional groups and sugar composition of quercetin derivatives on their radical scavenging properties / K. Kato, M. Ninomiya, K. Tanaka, M. Koketsu // J. Nat. Prod. - 2016. - Vol. 79, No. 7. - P. 1808-1814.

14. Novel quercetin derivatives: From redox properties to promising treatment of oxidative stress related diseases / P. Zizkova, M. Stefek, L. Rackova [et al.] // Chem. Biol. Interact. - 2017. - No. 265. - P. 36-46.

\section{REFERENCES}

1. Demkovych AYe, Bondarenko Yul. Changes of antioxidant potential under the experimental periodontitis development. Fiziolohichnyi zhurnal. 2018;64(3): 43-51.

2. Omarov Al, Bolevich S, Savateeva-Liubimova TN, Sivak KV. [Oxidative stress and complex antioxidant energy correction in the treatment of periodontitis]. Stomatolohiia. 2011;90(1): 10-7. Russian.

3. Nesterov YuV, Turchenko NV. [Structural features of the air-blood barrier of the lungs under conditions of acute hypo- and hyperoxic stress]. Estestvennye nauki. 2010;3: 112-6. Russian.

4. Sahiner UM, Birben E, Erzurum S, Sackesen C, Kalayci O. Oxidative stress in asthma. World Allergy Organ. 2011;4(10): 151-8.

5. Dahiya P, Kamal R, Gupta R, Bhardwaj R, Chaudhary K, Kaur S. Reactive oxygen species in periodontitis. J. Indian Soc Periodontol. 2013;17(4): 411-6.

6. Butiuhin YA, Volchehorskii YA. [The state of the system lipid peroxidation - antioxidant protection in mixed saliva in patients with chronic generalized periodontitis]. Klinicheskaya laboratornaya diagnostika. 2014;2: 44-7. Russian.

7. Duriahina LKh. Sedikh VP, Dorofieieva OV. [Influence of depressive disorders on the condition of periodontal tissues and oral mucosa]. Tavricheskiy medyko-biologicheskiy vestnik. 2014;17(1); 47-50. Ukrainian.

8. Genco RJ, Garcia WS, Compton R. Risk factors for periodontal disease. Risk assessment and periodontal pret vention in primary care. Periodontol. 2000. 2016;71(1): 1021.

9. Demkovych A. Effects of flavonol quercetin on activity of lipid peroxide oxidation in experimental bacterialimmune periodontitis. Interventional Medicine and Applied Science. 2019;11(1): 55-9.
15. Quercetin and derivatives: useful tools in inflammation and pain management / G. Carullo, A. R. Cappello, L. Frattaruolo [et al.] // Future Med. Chem. - 2017. - Vol. 9, No. 1. - P. 79-93.

16. Демкович А. $€$. Патогенетичні основи моделювання пародонтиту у тварин / А. Є Демкович, Ю. І. Бондаренко // Здобутки клінічної і експериментальної медицини. - 2015. - № 1 (22). - С. 54-57.

17. Сопоставление различных подходов к определению продуктов перекисного окисления липидов в гептан-изопропанольных екстрактах крови / И. А. Волчегорский, А. Г. Налимов, Б. Г. Яровинский, Р. И. Лифршиц // Вопр. мед. химии. - 1989. - № 1. - С. 127-130.

18. Berger R. L. Statistical Inference. Second Edition / R. L. Berger, G. Casella. - Florida: Duxbury Press, 2001. - 374 p.

10. Demkovych A, Bondarenko Yu, Hasiuk P. Effects of quercetin on antioxidant potential in the experimental periodontitis development. Interventional Medicine and Applied Science. 2019;11(1): 60-4.

11. Peng LX, Zou L, Wang JB, Zhao JL, Xiang DB, Zhao G. Flavonoids, antioxidant activity and aroma compounds analysis from different kinds of tartary buckwheat tea. Indian. J. Pharm. Sci. 2015;77(6): 661-7.

12. Ebrahimpour S, Esmaeili A, Beheshti S. Effect of quercetin-conjugated superparamagnetic iron oxide nanoparticles on diabetes-induced learning and memory impairment in rats. Int J Nanomedicine. 2018;13: 6311-24.

13. Kato K, Ninomiya M, Tanaka K, Koketsu M. Effects of functional groups and sugar composition of quercetin derivatives on their radical scavenging properties. J Nat Prod. 2016;79(7): 1808-14.

14. Zizkova P, Stefek M, Rackova L, Prnova M, Horakova L. Novel quercetin derivatives: From redox properties to promising treatment of oxidative stress related diseases. Chem Biol Interact. 2017;265: 36-46.

15. Carullo G, Cappello AR, Frattaruolo L, Badolato M, Armentano B, Aiello F. Quercetin and derivatives: useful tools in inflammation and pain management. Future Med Chem. 2017;9(1): 79-93.

16. Demkovych AYe, Bondarenko Yul. [Pathogenetic bases of modeling of periodontitis in animals]. Zdobutky klinichnoi i eksperymentalnoi medytsyny. 2015;1(22):54-7. Ukrainian.

17. Volchehorskyi YA, Nalimov AH, Yarovinskyi BH, Lifshits RY. [Comparison of different approaches to the determination of lipid peroxidation products in heptane-isopropanol blood extracts]. Vopr. med. khimii. 1989;1:127-130. Russian.

18. Berger RL, Casella G. Statistical Inference. Second Edition. Florida: Duxbury Press; 2001. 